\title{
地域リハビリテーションの動向とリハビリテーション医学の課題
}

\section{5．東京都区東部保健医療圈を中心とした地域リハビリテーション支援 センターの活動と課題}

東京都リハビリテーション病院 大塚 友吉

当院は東京都東部隅田川沿いに位置し, 区東部保健医療圈（人口約 120 万人）を中心に地 域リハ支援センターとして以下の活動をしている。（1 ) 地域り八従事者の研修支援：関節可 動域訓練や筋力増強訓練，基本動作訓練などのリ八基本手技の研修を，実技を交えて行って いる.（年に 6 8 回）（2 ) 直接地域住民と接する相談機関の支援：訪問リ八資源が圏内に少 なく，介護支援専門員等からのリハ相談（月に20～30 件）に応じ，訪問リ八を行っている. （月に 50〜70 件）（3）福祉用具・住宅改修等の相談への対応に係る支援：車椅子や杖の選定 や段差解消のための住宅改修の助言を行っている.（月に約 10 件）（4)地域の関係団体の支 援：医師会会員向けのリハセミナー (年 4 回), 介護保険関連連絡会（月 1 回）等に携わって いる.（5)連絡会・事例検討会の実施：ケアカンファレンスを含む事例検討会（不定期）に参 加し，リハ医療の面からの助言をするとともに，すみだ地域り八連絡会（平成 14 年 11 月発 足. 年 $3 \sim 4$ 回程度の連絡会開催予定）を結成し，リ八に関する諸問題を多職種で検討してい る.地域リハ支援センターの活動を通して見えてきた地域りハを推進するにあたっての課題 として以下の 3 点を強調したい.（1）地域りハの共通認識の欠如：地域りハに関係する医 療・保健・福祉・介護それぞれの職種間に地域リハのイメージや考え方，内容などに共通認 識が乏しい. ただ単に機能訓練=リハと考えている人も多い. もっと多相的な, 能力低下や 社会的不利に対するアプローチも地域リハであるとの認識がそしい.そのために医療・保 健・福祉・介護間の連携もうまくいかないように思われる.リハを進めるにはチームアプロ 一チが必要であり，地域におけるリハチームとなる医療・保健・福祉・介護の各職種の間で, リ八認識の共有は必須であろう。（2 )地域りハに携わるリ八専門職の絶対的不足：区東部保 健医療圏には，訪問リ八を行う施設・機関・事業所が少なく，自宅訪問や施設でのリハニー ドに充分に応えられていない。そのために，関節拘縮や移動や ADL 動作へのアプローチが 主体で, 興下や高次脳機能, あるいは痴呆等へのリハアプローチは地域リハの中では困難で ある、リハ医も病院内でのリ八医療の実践だけでなく, 自宅を含めた地域での患者の生活の 確認・指導のため, あるいは, リハ知識の普及のためにどんどん病院外に出ることを期待し たい.（3)各市区町村の独自性：介護保険制度の開始とともに, 各種保健・福祉サービスの 主体が市区町村に漸次委譲されつつあり，地域りハについても市区町村によりその実施体系 やサービス基盤整備への対応が異なっており，地域りハへの取り組みに地域差があること， 等が課題と考えられる. 